\title{
China: A candidate for winner in the international game of higher education?
}

\author{
ÁDÁM TÖRÖK ${ }^{1,2,3}$ (] and ANDREA MAGDA NAGY ${ }^{4}$ (10
}

${ }^{1}$ Hungarian Academy of Sciences, Budapest, Hungary

${ }^{2}$ Department of Economics, Budapest University of Technology and Economics, Budapest, Hungary

${ }^{3}$ Department of International Economics, University of Pannonia, Veszprém, Hungary

${ }^{4}$ Department of Economics, University of Pannonia, Egyetem u. 10, H-8200, Veszprém, Hungary

(C) 2020 The Author(s)

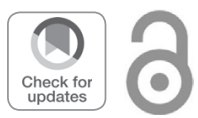

\begin{abstract}
The hegemony of the Western higher education institutions in the global university market is being challenged by China. The top Chinese universities have significantly improved their international ranking positions. When it comes, however, to the ability of universities to attract foreign students and faculty, the Chinese higher education institutions' performance raises questions. The International Outlook scores of these universities, although showing an increasing trend, are still lacking behind the U.S. or Western European top universities. China is primarily a student 'exporter.' It also became a leading destination country for students from Asia or Africa, but it is still far from reaching the 'international openness' level of the U.S. or the UK universities. The publication networks of the top Chinese higher education institutions indicate that these universities prefer to publish with other Chinese institutions or the U.S. universities.
\end{abstract}

\section{KEYWORDS}

China, higher education, university rankings, publication networks

\section{JEL CLASSIFICATION INDICES}

F16, F6, I23, I28

\footnotetext{
${ }^{*}$ Corresponding author. E-mail: nagy.andrea@gtk.uni-pannon.hu
} 


\section{INTRODUCTION}

The astonishing performance of the Chinese ${ }^{1}$ economy in the last three-four decades had its primary explanation in its fast-growing production as compared to rather low labour cost. More recent experience, though, speaks of an increasingly technology-driven growth path in China, with armies of highly skilled manpower entering the labour market each year. In the background of this, a very competitive university sector seems to be emerging. Not only diverse international higher education ranking lists provide convincing evidence on this, but also the fact that top Chinese decision makers have elevated the sector to political priority. One of the signs of this is the leading role of Academic Ranking of World Universities (ARWU) of Shanghai among the most widely cited ranking lists of the world of international higher education.

We faced three research issues during our research. First, we were interested in the extent to which the widespread, also press-generated impression of improving ranking positions of the Chinese universities in the lists is supported by facts. Second, our intent was to explore the intensity of internationalisation efforts as a tool of improving global reputation. And third, we set the task to assess the role of joining international research networks in improving ranking positions.

In a first step, the Times Higher Education World University Rankings (THE), Academic Ranking of World Universities ARWU and QS World University Ranking ranking positions of the leading Chinese universities are compared. Special emphasis is put on the ability of the Chinese universities to attract international students and international faculty members. The International Outlook scores of THE and the International Faculty and International Student scores of QS are used to measure 'international openness' (IO). The co-authored publication networks of the top Chinese universities are also examined and compared with the publication networks of the TOP25 THE universities.

\section{TOWARDS BUILDING A WIDER ELITE? SOME REMARKS ON CHINESE POLICIES OF HIGHER EDUCATION}

One of the main goals of both the Chinese academic community and the central government has been to establish 'world-class universities'. Although there are a great number of universities in mainland China and some of them have actually worldwide reputations to some extent, they rarely get top positions.

The initiative for building elite universities (or world class universities) was started by the Ministry of Education of China. Two major projects, 'Project 211' and 'Project 985' were aimed at this. Both projects were financed by the Ministry of Education and local governments (Shen 2018). Related projects like 'Project 863' and 'Project 973' were also introduced. 'Project 863' focuses on research and development of advanced technologies, while 'Project 973' supports basic ('exploratory') research. All four projects require large amounts of investment in science and technology. The Chinese universities have received a considerable share of the funding from these projects for their research (Li 2010).

${ }^{1}$ In this paper China Mainland is analysed (without Macau, Hong Kong and Taiwan). 
A possible strategy for governments to build world-class higher education (HE) institutions would be to firstly consider upgrading a small number of existing universities that have the potential of excelling. They should, in other words, 'pick the winners.' As a next step, they should encourage a number of existing institutions to merge and transform into a new university that would achieve the type of synergies corresponding to a world-class institution (Salmi 2009).

Foreign countries (mainly the Japanese or the U.S. models) had a great influence on the modern Chinese HE system already in the early 20th century (see e.g. Yang 2006). Later on, the war with Japan and the civil wars hindered the growth and development of the Chinese HE system. From 1949 onwards, it switched to the Soviet model which, for the next 16 years, generated rapid economic growth starting from a very low level of development.

The Cultural Revolution of 1966-1976 had a devastating impact on the Chinese HE system. Many colleges and universities were closed or gave up functioning. National entry exams for HE were terminated. No new students were admitted to colleges or universities. Classes, the grading system and curricula were not following the previous academic standards.

With the beginning of the economic reforms of 1978, HE in China began expanding rapidly again. The Chinese government implemented several major market-oriented reforms. These were largely fuelled by a huge and rapidly growing population (Nofri 2015). For example, the traditional command system on admission and placement was abandoned so as to give schools some flexibility in enrolment. Traditionally free HE was transformed to a tuition-based system. A more favourable approach towards private education was also gradually adopted. By 1991 the government had started to recognise independent colleges. These colleges generally had a lower reputation than the university system, but they were useful in satisfying increasing demand (Nofri 2015). The Chinese HE institutions became more open to other countries. The government also encouraged collaborations and exchanges with universities worldwide.

In 'Project 211' around 116 universities and three university-affiliated medical schools were covered, while the focus of 'Project 985' was to support the elite HE institutions in becoming world-class universities. Interestingly, this referred to only two institutions, the Peking and the Tsinghua University. The list of the target universities was later expanded to include another seven. At the moment, 39 universities are involved, although merely the first nine are outstanding and represent the top HE institutions of China. 'Project 985' seems to put more emphasis on the creation of elite universities, rather than a world elite HE system. For example, through this project the C9 League, an official alliance between the nine universities of China, was launched (see e.g. People's Daily 2009). The supremacy of the nine 'best' universities compared to other Chinese universities is clearly visible in the THE, ARWU and the QS international university rankings. The 'Double First-Class University Plan' was launched in 2017. This one is aimed at comprehensively developing elite Chinese universities into world-class institutions until 2050. It is, however, not clear whether this plan is meant to replace or rather complement the previous projects (Australian Government 2020).

Building research excellence became also a key element of the strategy towards achieving world-class status for certain universities. The government has placed great efforts on strengthening the research functions of universities, including enlarging the scale of graduate education, increasing funding, and laying the foundations for promoting high quality research in universities (see e.g. Double First-Class University Plan) (Shen 2018). Liu (2007), who provided an overview of the research universities in China, emphasised the importance of establishing classification criteria for this type of universities. These universities have been differentiated 
from others through government policies and university rankings, but there are no clear definitions and classification criteria for them.

Yaisawarng - Ng (2014) assessed the impact of 'Project 211' on the research performance of the universities. They showed that the 'Project 211' universities, on average, performed better than the non-Project 211 group. The authors concluded that HE reforms should be broadened in order for the non-Project 211 universities to be able to enhance their research capabilities.

The National Medium- and Long-term Talent Development Plan (2010-2020) was another attempt of coordination. The aim of the government was to establish higher-education research bases in central and Western provinces and increase national tertiary enrolment rates to 40 per cent (China Power Team 2016). The outcome of this plan is unknown, as yet.

All the projects mentioned above were aimed at creating elite universities. Interestingly, however, in a 2020 document released by the Ministry of Education and Ministry of Science and Technology, 'excessive reliance' on Science Citation Index (SCI) papers for allocation of research funding and academic promotions was proposed to be reduced. This can be regarded as stepping away from the publish-or-perish culture which pushed Chinese researchers and academics towards international publications. Many fear that this will result in a fall of the elite Chinese universities in the global university rankings (Sharma 2020).

University mergers have been also used to support the overall objectives. It is believed that mergers can help the leading universities build up sufficiently large capacities (Ma 2007). It is, however, not clear, whether such practices can indeed increase the quality of teaching and enhance the scientific performance of the institutions. A paper examined the impact of mergers on the production of publications for 29 Chinese university mergers and 8 North European university (from Denmark, Sweden and Finland) mergers. It was found that the Chinese universities exhibited a small but significant increase in the rate of growth of articles following a merger, while for the Nordic universities the effect was less clear cut. The authors also concluded that the mergers of similarly sized institutions usually have little impact on research performance, while mergers between a large comprehensive university and much smaller universities have a positive impact on overall publications (Liu et al. 2018).

Other reform methods included, for example, name changes. A study showed that renaming an institution from a college to a university and incorporating the name of a large regional area may lead to a significant improvement in admission scores (Shi et al. 2020). A 'massification' of the HE system took also place starting from 1999. For example, a number of colleges that provided short-cycle degrees were upgraded to the undergraduate level and became eligible to grant bachelor's degrees (Shen 2018). The expansion of the Chinese HE system, however, has not weakened the pursuit of elitism in HE, but rather became a second university sector meant to help strengthen the elite (Teichler 2010; Nofri 2015). Thus, a hierarchical structure in the Chinese HE system has been 'created.'

The results of these policy measures got very controversial assessments in literature. Some think that the Chinese government, by keeping the educational levels separate, managed to please both groups: students have more opportunities to enter academic courses of study, while those looking for excellent education, can still apply to highly ranked universities (Nofri 2015). Others regard the aggressive and wide-spread pursuit of building world-class universities coupled with an inside need for expanding higher education as a mean to create an extremely stratified system (Shen 2018). According to this group, although the aim of the 'massification' 
was to reduce inequity in China, the structure of HE makes it almost impossible for low socioeconomic status students to access the elite Chinese universities (e.g. Luo et al. 2018).

Arguably, top universities are highly selective and the admission process is extremely competitive (not to say tough). For example, Peking University applicants who are from Beijing are estimated to have a 0.5 per cent chance of acceptance into a bachelor's programme (the number of applicants is not made public), this is up to 40 times higher than for applicants from other parts of the country. ${ }^{2}$ These admission rates are low even compared to universities such as Harvard University $\left(4.92 \%\right.$ in $\left.2020^{3}\right)$, Stanford University $(4.36 \%$ for undergraduate students $\left.2018^{4}\right)$ or University of Oxford $\left(15.38 \%\right.$ for undergraduate students $-2018^{5}$ ) or University of Cambridge (18.85\% total applicants/students admitted $\left.-2018^{6}\right)$.

The elite universities are concentrated in wealthy municipalities and provinces. Five of the top ten Chinese universities are in Beijing and Shanghai. Shanghai, one of China's wealthiest municipalities, has an enrolment rate of 70 per cent in HE, while provinces like Guangxi have enrolment rates below 20 per cent (China Power Team 2016). All these have an effect not only on the financial background of the universities and colleges, but also on their ability to attract further funds (especially research funds) as well as on the development possibilities of the cities in which these institutions are located.

Interestingly, the Belt and Road Initiative (BRI), adopted by the Chinese government in 2013, has also an effect on the HE system. The number of students from countries along the 'Road,' for example the Central Asian countries, has significantly increased during the recent years (Linney 2020).

As many international institutions prioritize recruiting from Asia, and especially China (e.g. Sanger - Baer 2019), competition for students is quite harsh for the Chinese universities. Chinese graduate students traditionally prefer to study in science fields such as physics and mathematics, or business, economics, law and medicine. Their first destination is the U.S. (see e.g. Global Flow of Tertiary-Level Students, UNESCO database). Taking a look at China's HE system as a possible destination for international students, one can see that it still lacks behind developed countries such as the U.S., the United Kingdom, Germany or France, although its ability to attract students and faculty from abroad is growing. A major problem in this regard is the language barrier. Many international students complain about poor command of English of the Chinese university staff members (China Education Center 2020; Luo - Qin 2012).

Another issue is the political influence on every aspect of teaching and research (Li 2010). According to Li-Yang (2014), the situation has started to change with the announcement of China's National Plan for Medium and Long-term Education Reform and Development (20102020). The central government controls the extent, process, and pace of decentralisation, while

\footnotetext{
${ }^{2}$ China Power Team, 2016. These numbers were retrieved from https://chinapower.csis.org/education-in-china/. They should be used with caution.

${ }^{3}$ Source: https://www.thecrimson.com/article/2020/3/27/harvard-admissions-2024/ (Retrieved at 22 May 2020).

${ }^{4}$ Own calculation using data from https://admission.stanford.edu/apply/selection/statistics.html (Retrieved at $22 \mathrm{May}$ 2020).

${ }^{5}$ Own calculation using data from https://worldscholarshipforum.com/the-university-of-oxford-acceptance-rate/ (Retrieved at 22 May 2020).

${ }^{6}$ Own calculation using data from https://www.undergraduate.study.cam.ac.uk/sites/www.undergraduate.study.cam.ac. uk/files/publications/ug_admissions_statistics_2018_cycle.pdf (Retrieved at 20 May 2020).
} 
provincial governments and HE institutions are granted more freedom and rights. More autonomy has been granted to the institutional level on financial and academic matters (e.g. the appointment of academic staff and administrators, curriculum, and course development and recruitment of students). The authors use the term 'semi-independence' for the situation and describe it as 'the paradox of centralised decentralisation' (Li-Yang 2014). This, however, changed with Xi Jinping becoming the General Secretary of the Communist Party of China in 2013 (see e.g. the Fudan student protest in December, 20197). In 2016, Xi himself declared that he wanted to turn university campuses into 'strongholds of the Party's leadership.' According to Taber (2018), the authorities want to use the 'ivory tower' of universities as a tool for developing sophisticated propaganda techniques.

Tuition fees represent an increasing financial burden for families. The objectives of master's programs are not well defined, and it is unclear whether such programs are expected to train researchers or just to offer a higher academic degree. A large number of government officials and business executives are getting their doctoral degrees (mostly in economics and business-related disciplines) on a part-time basis. $\mathrm{Li}$ (2010) calls this trend a desire for 'window- dressing' from those in control of administrative and financial resources and concludes that this can compromise efforts to improve the quality of doctoral education. Xin - Normile (2008) discussed issues related to the Chinese universities in their efforts to become world-class institutions and concluded that problems such as their mounting debt are still waiting to be solved.

\section{DATA AND RESEARCH QUESTIONS}

We used for our analysis the following rankings: Times HE Ranking (THE), the ARWU and the QS World University Rankings (QS). Publication networks were identified using the publication data of Clarivate's Web of Science database and the Gephi Visualization Platform.

The analysis evolved around two major aspects of top Chinese universities:

- The international ranking positions of the best universities:

changes of ranking scores over the analysed time period,

changes of the number of Chinese universities in the international rankings over the years analysed,

possible differences between the ARWU and the THE, QS rankings.

- The 'international openness' (IO) of the top universities in China:

analysis of the International Outlook, International Faculty and International Student scores, the publication networks of the universities measured by co-authored publications.

\footnotetext{
${ }^{7}$ In the December of 2019, Fudan University changed its charter to emphasise loyalty to the CPC. The authorities downgraded or erased references to academic freedom from their charters. Students protested against this change. According to Feng - Cheng (2020), the charter change is part of a broader trend that has been growing since Xi Jinping became China's leader (2013). From 2013 to 2017, at least 109 universities unveiled their first-ever charters to highlight their loyalty towards the Party.
} 


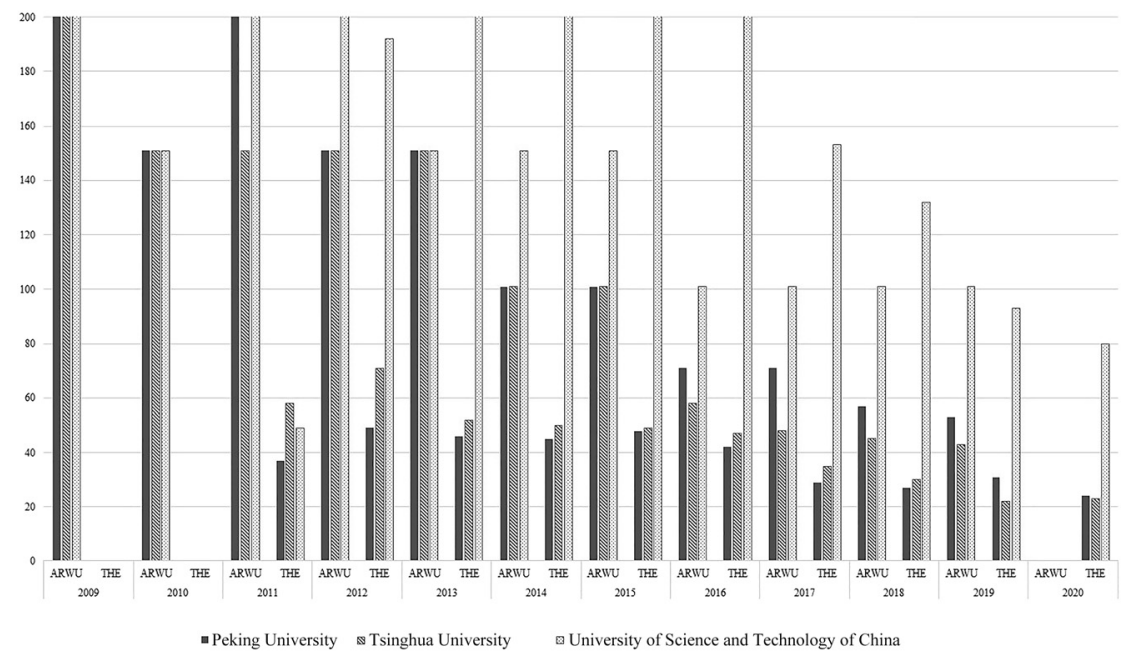

Figure 1. ARWU (2009-2019) and THE (2012-2020) ranking of the top Chinese universities Sources: THE and ARWU database, own compilation.

\section{OVERALL RANKING POSITIONS}

We focused on three questions. The first one evolved around the rankings of the Chinese universities and the changes in their positions from 2011 until 2019/2020. The second research question focused on IO of these institutions. The later was measured using the International Outlook scores published by the THE ranking and the International Faculty and International Students scores of the QS World University Ranking.

The change in the ARWU (between 2009 and $\left.2019^{8}\right)$ and the THE $\left(2011^{9}\right.$ and $\left.2020^{10}\right)$ ranking positions of the top 3 Chinese universities (top 3 according to the THE ranking, 2020) can be seen in Figure 1. Basically, the top two higher education institutions have improved their positions during the periods of time analysed. Interestingly, in the ARWU 2019 ranking, there were no Chinese universities in the top 25. Tsinghua University (based in Beijing) was only at 43, while Peking University ranked 53. In the THE, these two universities were included in the top 25 (ranked 23rd and 24th). The University of Science and Technology of China showed strange

${ }^{8}$ The 2020 ARWU international university ranking was not yet published.

${ }^{9}$ The THE changed the name of the rankings during the analysed years. From 2011 until 2017, the published rankings were World University Rankings 2010-2011, 2011-2012, 2012-2013, 2013-2014, 2014-2015 and 2016-2017. In our analysis we indicated these rankings with the second year (e.g. World University Rankings 2010-2011 - the ranking from 2011). From 2018 the name changed to World University Rankings 2018, 2019 and 2020.

${ }^{10}$ THE publishes individually (without QS) rankings from 2011, but we chose as a starting date 2012. In the 2010/2011 ranking there were only 6 Chinese universities listed. Important universities such as Fudan and Shanghai Jiao Tong Universities were ranked from 2012. Also, in 2011 the International Outlook scores were calculated for only 5 Chinese HE institutions. 


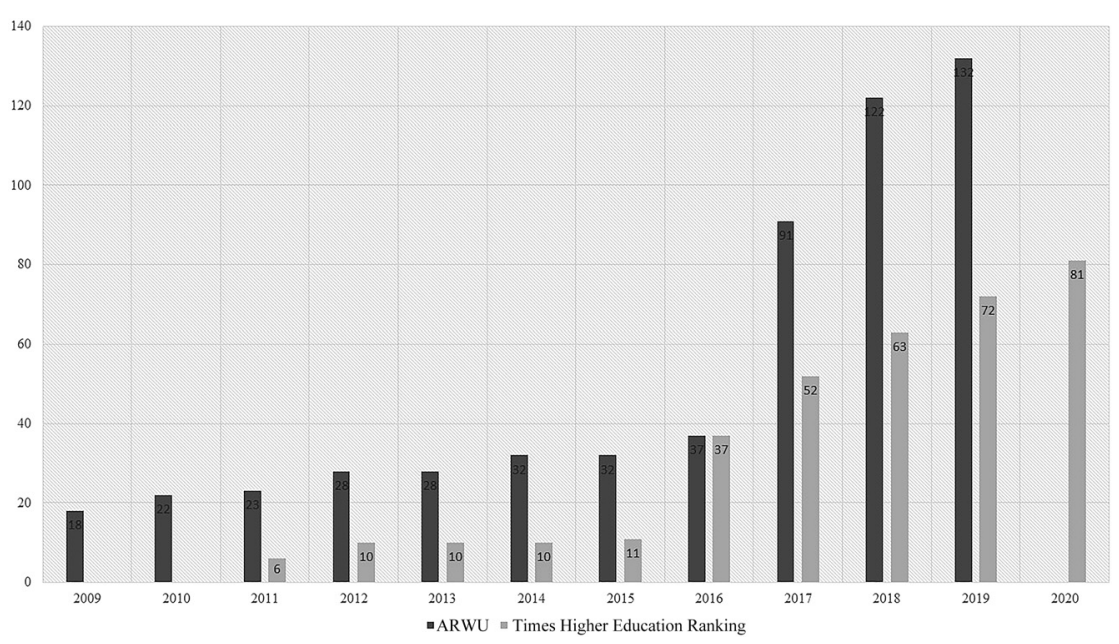

Figure 2. Number of Chinese universities in the ARWU and in the THE rankings Sources: THE and ARWU database, own compilation.

position changes. It has fallen back from 49 (2011) to 192 (2012) and later to 201-225 (20142016). It started to improve its ranking only from 2017 and in 2020 reached the 80th position.

The QS World University Rankings are available for China only from 2017. In the TOP25 (QS 2020), there were two Chinese universities, Tsinghua University was ranked 16, while Peking University was 22nd.

Our comparison of the three rankings can be seen in Appendix 1. The top three universities are highlighted. By all three world university rankings, a slight improvement in the positions of the Chinese universities can be observed.

The number of the Chinese HE institutions in the ARWU and THE rankings were also analysed (Figure 2). A trend of improvement can be observed. In 2016, both THE and ARWU listed 37 universities. There is, however, a huge leap in the ARWU ranking between 2017 and 2018: the number of the Chinese institutions listed here increased dramatically, from 37 to $91 .^{11}$

The ranking positions do not seem to speak of significant differences, but the number of the Chinese universities shows great discrepancies. For example, in 2019 there were 72 Chinese HE institutions in the THE ranking, while in the ARWU their number was almost the double, 132. The QS ranking listed only $40 \mathrm{HE}$ institutions from China (Mainland) in 2019. Although their number increased from 2017 until 2019 (from 33 to 40), it is still very low compared to the other two rankings (ARWU 132, THE 72). ${ }^{12}$

Two tendencies can be identified from the international university rankings. The number of the Chinese universities listed has drastically increased, while the positions of these show only a

\footnotetext{
${ }^{11}$ It has to be noted that from 2017 ARWU enlists 1,000 universities while previously only 500 were taken in consideration.

${ }^{12}$ The QS Ranking, as the ARWU, enlists 1,000 universities.
} 
slight improvement. The major difference between the THE, QS and ARWU rankings is in the numbers of the Chinese HE institutions included.

A Pearson index was calculated to measure the correlation regarding the rankings of the HE institutions of China (Appendix 2). All correlation coefficients are positive, robust and significant at the 5\% level. A positive strong correlation between ARWU - QS and ARWU - THE also exists, although with a slightly lower coefficient by the THE - QS pair.

Overall, the HE institutions of China are characterised quite similarly by all three world university rankings. Although the ARWU ranking is operated by a Chinese organisation (Shanghai Ranking Consultancy), it does not seem to especially benefit the top Chinese universities. In the 2019 QS and THE ranking Tsinghua and Peking Universities were among the top25, while by ARWU they only got into the top50. One question mark, however, remains regarding the ARWU and its relationship with the Chinese universities. Why are 132 Chinese universities listed in this ranking, while by the other international rankings their respective numbers are only 72 and 42 ?

\subsection{International openness (10)}

IO has become a key variable of ranking lists. It is defined as the ability and willingness of HE institutions to attract foreign students, faculty members and to publish with researchers from other countries. When it comes to sending students to other countries, China is a leading student 'exporter.' $17.5 \%$ of the global number of mobile students are Chinese. ${ }^{13}$ The net flow of internationally mobile students (inbound - outbound) is negative, meaning the outflow is higher than the inflow. ${ }^{14}$

The total number of foreign students in China increased over recent years. In 2018, 492,185 foreign students from 196 different countries and regions were studying at the Chinese universities and academic institutions. The main sender countries are from Asia (e.g. South Korea). African countries seem to also have an increasing interest in sending their students to China (2,000 students in 2013, while 50,000 in 2015) (Textor 2019).

The Chinese Ministry of Education estimated that more than 600,000 Chinese students left the country to pursue advanced studies overseas in 2017. Interestingly, the number of returnees surpassed 480,000 . This was $11.19 \%$ higher than in the previous year. A survey (The Chinese Students Overseas Study White Paper) found that $46 \%$ of students had no intention of emigrating after graduation. This ratio was $39 \%$ in 2017 and $35 \%$ in 2016 . Over half of those surveyed plan to return to China after gaining foreign work experience (Wang 2018).

The question arises whether the Chinese universities are as open internationally on the receiving side as on the sending one. Also, how open are they when it comes to receiving international faculty members or publishing in teams with scientists from other countries? Openness was measured using the international outlook scores of the THE, and the international faculty and international student scores of the QS ranking. The ARWU ranking does not publish scores for IO.

The THE calculates an International Outlook Score. This index has three pillars: international students, international faculty and international collaboration. Its aim is to measure the ability of a given 'university to attract undergraduates, postgraduates and faculty from all over

\footnotetext{
${ }^{13}$ Source: http://uis.unesco.org/en/uis-student-flow, retrieved at 24 April 2020.

${ }^{14}$ Source: http://data.uis.unesco.org/index.aspx?queryid=169, retrieved at 10 May 2020.
} 


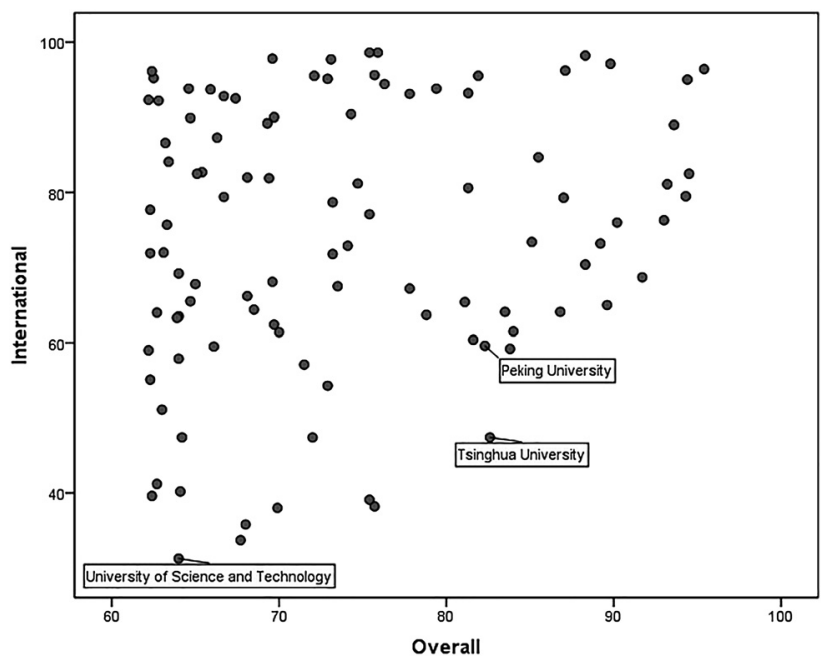

Figure 3. Overall, vs. International Outlook scores for the TOP100 universities in the THE, 2020 Sources: THE database, own compilation and calculation.

the planet.' ${ }^{15}$ Compared to other top universities, the Chinese HE institutions seem to be internationally less open than their counterparts abroad.

The Overall and International Outlook scores of the TOP100 universities of the THE ranking (2020) have also been examined (Figure 3). According to it, there are three Chinese universities among the best HE institutions of the world (Tsinghua University, Peking University and University of Science and Technology of China (this one ranked 82)). Most universities in our comparison seem to have a quite high International Outlook score. Universities with a higher than 80 Overall score have also an International Outlook score above 50. There is one exception, Tsinghua University. It has a quite high Overall score, while its International Outlook score is very low, compared, at least, to other TOP universities with their above 80 Overall scores.

Among the universities with Overall scores below 80, there are HE institutions with very high International Outlook scores (e.g. University of Manchester - 90; UNSW Sidney - 93.70; Chinese University of Hong Kong - 97.80). Some universities, however, reached a very low International Outlook score. One of them is the third Chinese university in the TOP100, the University of Science and Technology of China (Overall score 64; International Outlook score 31.30). In summary, the universities of the TOP 100 THE ranking show a very diverse picture regarding IO. The values of International Outlook index vary between 31.30 and 98.60. When it comes to the top Chinese universities, their scores are quite low compared to their counterparts. All three of them have values below 60, while their Overall scores are between 82.6 and 64.0.

\footnotetext{
${ }^{15}$ Source: https://www.timeshighereducation.com/world-university-rankings/world-university-rankings-2020methodology. Retrieved at 24 April 2020.
} 
The International Outlook scores for the TOP25 universities of the THE ranking have also been examined. The mean of the international outlook score is 77.34 , while the minimum is 47.4 and the maximum is 98.20 . The minimum score here belongs to Tsinghua University from China (ranked 23 according to the 2020 ranking). There are two other universities with a score lower than 60. One of them is University of Michigan-Ann Arbor, United States, while the other is Peking University (ranked 24 according to the 2020 ranking). Standard deviation is 14.27 . The QS ranking calculates scores for International Faculty and International Students indices. These have been analysed for the TOP25 universities. By International Faculty, the minimum score is 11.1 (University of Tokyo), while the maximum is 100 . The mean is 82.82 and the standard deviation is 22.42. The value for Tsinghua University is 68 . Peking University has a similar value, 70.70. These values are higher than the minimum value, but they still do not reach the average value of the top25 universities. By the International Students index the minimum score is 26.2 (University of Tokyo), while here the maximum is also 100. The mean is 74.86 and the standard deviation is 23.256. The scores for both top Chinese universities are very low, 30.1 and 36.9. They are just a few points away from the minimum, and quite far from the mean. This indicates that these universities, at least in a comparative sense, lack international students.

To get a clearer picture about the IO of the best Chinese HE institutions, all those Chinese universities in the THE and QS rankings have been analysed which received International Faculty, International Student and International Outlook scores (Appendix 3). The International Outlook scores of these institutions are below 62. The highest score (61.8 according to the 2020 Times Higher Education Ranking) belongs to Zhejiang University (ranked 107). The lowest score belongs to the University of Science and Technology Beijing (2.3). The mean value of the International Outlook score for the analysed Chinese universities is 38.65. The standard deviation is 12.75. Tsinghua University is the first Chinese university in the world in this comparison since the THE ranking places it at 23rd. The international outlook score of this university, however, is very low, 47.4 out of 100 .

When it comes to the International Faculty and International Students indices, Zhejiang University got the highest scores in China, 95.40 and $62.90 .^{16}$ The mean value of the International Faculty index is 15.93, while for the International Students it is 37.05. The standard deviations are 15.25 and 31.94, respectively. The lowest International Faculty score belongs to Jilin University (3), while the minimum International Student score was calculated for the Beijing Institute of Technology (5). The International Faculty and International Student scores for the best Chinese University (Tsinghua University) are also quite low (30.1 and 68, respectively). It seems that, although it is the 'best,' its ability to attract international students and faculty members is still quite low.

All HE institutions which received International Outlook scores in at least six years during 2011-2020 were taken into consideration (Figure 4). This meant 13 universities. Their scores in 2011 and 2018-2020 were relatively high, while most of them suffered a decrease between 2012 and 2017. This can be a result of a change in the Chinese government's attitude towards science, starting to cut back academic freedom also in the universities. The scores showed a quite high

\footnotetext{
${ }^{16}$ Interestingly, there was one Chinese university (Xi'an Jiatong Liverpool University) which received 100 for the International Student index. This higher education institution was, however, founded through a partnership between University of Liverpool and Xi'an Jiatong University. It was not analysed in this paper, as it did not receive any scores for International Faculty and International Outlook.
} 


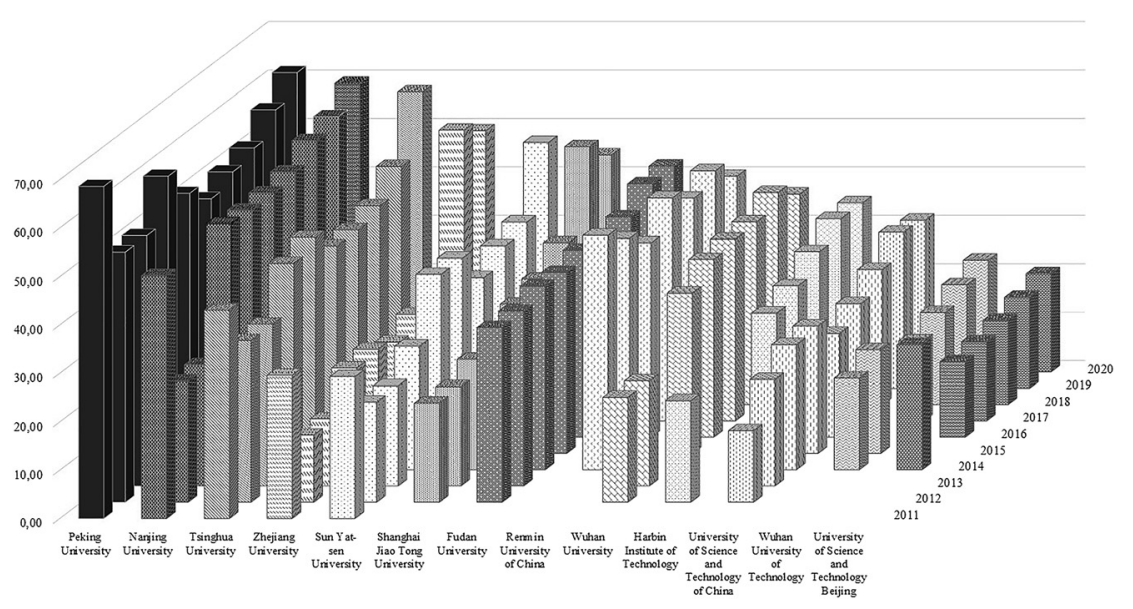

Figure 4. International Outlook scores for the best Chinese universities, 2011-2020

Sources: THE database, own compilation.

volatility during the years analysed (except Fudan University and Renmin University of China). The score of Zhejiang University changed the most: starting from 29.6 (2011) it reached 61.8 in 2020.

The ability of the top Chinese universities to attract international students and faculty members is somewhat an ambiguous topic. There are articles which suggest that the Chinese government and the Chinese HE institutions are enhancing their IO. This in turn might make China an increasingly important destination for international students in the future (see e.g. Li 2010). Also, institutes such as the Confucius Institute (CI) promote cultural exchange and have an active role in bringing more foreign students to study in China (Lien-Miao 2018). The later can be a great obstacle for attracting foreigners.

\subsection{Publication networks of the TOP Chinese universities}

We analysed also the publication networks of the five best universities: Fudan, Peking, Shanghai Jiao Tong, Tsinghua and Zhejiang Universities. These universities belong to the C9 League. For visualisation purposes only the TOP50 publication partners were taken into consideration (later referred to as TOP50 publication network). These are the ones with which the analysed universities had the most co-authored publications between 1975 and 2020. ${ }^{17}$ The nodes represent the institutions, while the size of edges show the number of co-authored publications during the analysed time period (Figure 5).

All Chinese universities, except Tsinghua University, had the other four top universities as partners in their TOP50. The Chinese TOP universities prefer publishing with other Chinese

\footnotetext{
${ }^{17}$ Until 17 April 2020, the date of the data retrieval.
} 


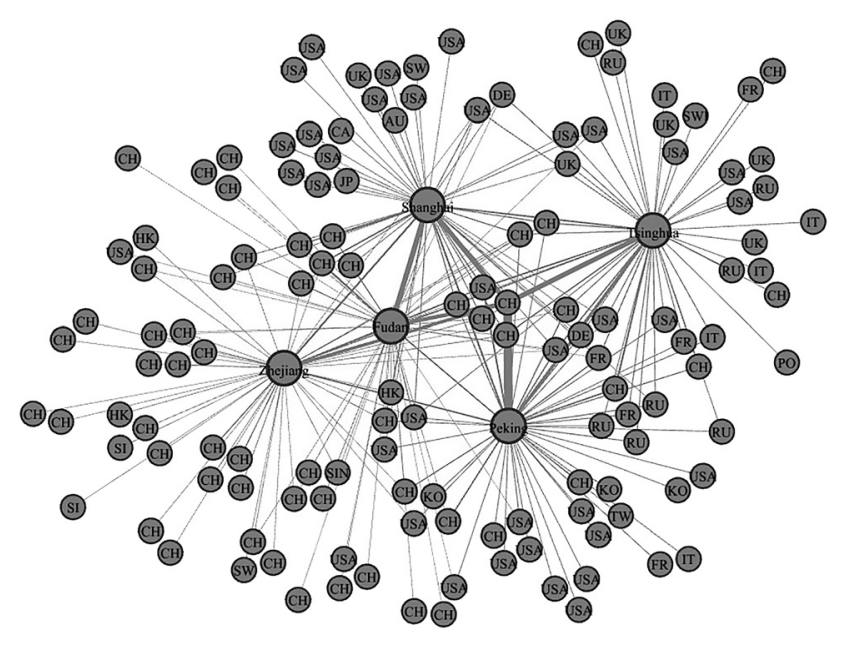

Figure 5. Publication network of five Chinese universities

Sources: Web of Science database, own compilation and calculation.

universities (especially other top universities). Tsinghua University, Shanghai Jiao Tong University and to some extent Peking University have the highest number of international links in their TOP50 publication networks. All other universities prefer Chinese institutions as partners in publishing. This, of course, does not mean that they do not publish with foreign researchers, but most of their publications are still with the institutions from China. Their most preferred foreign institutions are from the USA, from the EU (especially France, Germany, Italy, Spain and the $\mathrm{UK}^{18}$ ) and interestingly Russia. Geographically neighbouring countries are not between the preferred ones when it comes to publications.

The publication networks of the top $25 \mathrm{HE}$ institutions of the THE have been also analysed ${ }^{19}$ (Figure 6). Three universities were omitted from the analyses, as the search for their publications in the Web of Science database was inconclusive. ${ }^{20}$ This list contains two Chinese universities, Tsinghua University (ranked 23) and Peking University (ranked 24). The most preferred publication partners (top50) were categorised into 'Innerland' and the 'Rest of the world.'

The group 'Innerland' contained all institutions from the same country as the university analysed. It turned out that the universities from USA have the highest Innerland ratio (Innerland divided by the total number of institutions (50)). Their most preferred publication partners are from their home country. In some universities such as Northwestern University or Johns Hopkins University more than $90 \%$ of the TOP50 publication partners are from the USA.

\footnotetext{
${ }^{18}$ For visual purposes the EU and the UK were kept in the same group.

${ }^{19}$ THE 2020 Ranks were used.

${ }^{20}$ The three universities have similar names (California Institute of Technology, University of California, Berkeley and University of California, Los Angeles) and that is why the search was inconclusive. The publications of the three institutions could not be differentiated.
} 


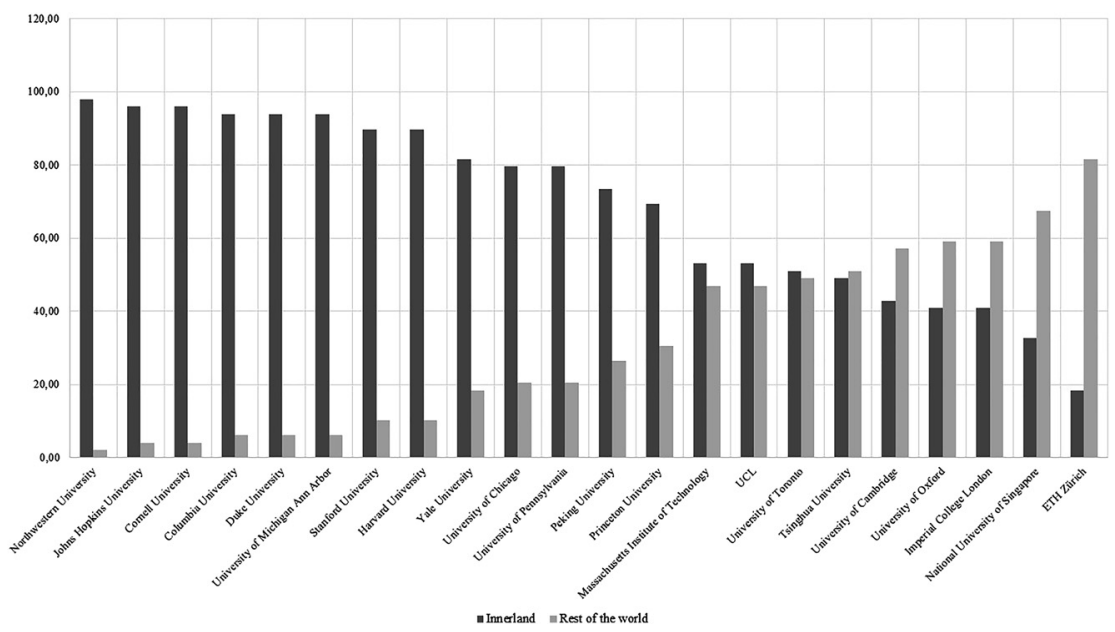

Figure 6. Publication networks of the TOP25 universities in the THE, 2020

Source: Web of Science and THE database, own compilation and calculation.

Peking University has also a quite high 'Innerland' ratio, 73.74. Interestingly, Tsinghua University seems to be more open: the 'Rest of the world' ratio (rest of the world divided by the total number of institutions (50)) is higher than the 'Innerland' ratio (48.98 compared to 51.02). The difference between the publication networks of the two top Chinese universities can be seen in Figure 5 as well. The universities with the highest 'Rest of the world' ratio are from the European countries and Singapore.

Most scholars at the top Chinese universities prefer colleagues from other Chinese institutions as their publication partners. The publication links between the top HE institutions from China are very strong. The best two Chinese universities have quite intense publication links with institutions from the USA, EU (and Switzerland) and Canada, although their major partners are also other Chinese institutions. Interestingly, the best universities from the USA and also the world have similar, quite introverted co-authoring patterns. Geographical proximity does not seem to play a major role in choosing publication partners.

\section{CONCLUSION}

Our research strategy is based on the assumption that the gradual opening and the impressive growth of the Chinese economy should be both reflected and supported by a comparable performance in the sector of HE. Our results drawn from an in-depth analysis of three of the most often quoted international ranking lists of HE institutions do not completely contradict this hypothesis, but they still have a somewhat ambiguous character.

To begin with, some Chinese universities have fared very well since about the year 2000 in regard of getting close to the top of international ranking lists. Yes, they have come close to the 
top: at least half a dozen of them made it to the first 50. This would be an unheard-of achievement for most, if not all universities of Central Eastern Europe. To be more accurate however: very few Chinese universities could make it to the absolute top of 25, still largely dominated by schools from the English-speaking world.

Our survey of the strategic documents of Chinese policies of HE has, however, made it evident that Chinese ambitions are twofold in this respect. First, they do not hesitate to use generous government funding in order to catapult their best universities up to the absolute top. Second, they use selective policies of university development in order to create nests of reproduction for their professional and political elites. While we cannot assess the success of the second effort, the first one seems to be, at best, only partially accomplished.

Our assessment of the international dimension of the strategy outlined above may have delivered a limited explanation of this partial success. It seems that most leading Chinese universities do not sufficiently focus on international co-operation in several respects. Their readiness to hire foreign teaching and research staff is still limited, and they prefer sending their students abroad instead of receiving students from abroad. Our latter observation could, however, be explained in part by the difficulties for foreigners of learning the Chinese language.

The publication strategies of the Chinese universities also show certain components of their mostly low levels of international exposure. Their interest in being involved in international publication networks is quite low yet, which has a certain negative influence on their indicators of international co-operation in the ranking lists. We would like to be more than careful in trying to attribute this apparent lack of interest in creating international networks of research to any kind of political factor.

\section{ACKNOWLEDGEMENT}

The authors would like to thank Frank Strack (MA student, University of Pannonia) for his help in collecting data and literature.

\section{REFERENCES}

Academic Ranking of World Universities. http://www.shanghairanking.com/ARWU2019.html. Retrieved at 4 April 2020.

Australian Government, Department of Education: Skills and Employment, 2020. https:// internationaleducation.gov.au/News/Latest-News/Pages/China-sets-direction-for-world-classuniversities.aspx. Retrieved at 9 May 2020.

China Education Center, 2020. https://www.chinaeducenter.com/en/university/englishtaughtprogram.php. Retrieved at 5 May 2020.

China Power Team (2016): How does Education in China Compare with Other Countries? https:// chinapower.csis.org/education-in-china/. Retrieved 10 May 2020. 
Feng, E. - Cheng, A. (2020): Chinese Universities are Enshrining Communist Party Control in their Charters. https://www.npr.org/2020/01/20/796377204/chinese-universities-are-enshrining-communistparty-control-in-their-charters $? \mathrm{t}=1585998054114 \& \mathrm{t}=1588868192356$. Retrieved at 8 May 2020.

Global Flow of Tertiary-Level Students, UNESCO database. http://uis.unesco.org/en/uis-student-flow. Retrieved at 5 May 2020.

Li, H. (2010): Higher Education in China: Complement or Competition to US Universities? In: Charles, T. C. (ed.): American Universities in a Global Market. Chicago: University of Chicago Press, pp. 269-304.

Li, M. - Yang, R. (2014): Governance Reforms in Higher Education: A Study of China. IIEP Research Papers, pp. 1-54.

Lien, D. - Miao, L. (2018): Effects of Confucius Institutes on China's Higher Education Exports: Evidence from Chinese Partner Universities. International Review of Economics \& Finance, 57(September): 134143.

Linney, A. (2020): How China's Belt and Road Initiative is Impacting Higher Education on Global Scale. https://www.qs.com/chinas-belt-initiative-impacting-he-global-scale/. Retrieved at 5 May 2020.

Liu, N. C. (2007): Research Universities in China: Differentiation, Classification, and Future World-Class Status. In: Altbach, P. G. - Balán, J. (eds): World Class Worldwide: Transforming Research Universities in Asia and Latin America. Baltimore: The John Hopkins University Press, pp. 54-69.

Liu, Q. - Patton, D. - Kenney, M. (2018): Do University Mergers Create Academic Synergy? Evidence from China and the Nordic Countries. Research Policy, 47(1): 98-107.

Luo, Y. - Guo, F. - Shi, J. (2018): Expansion and Inequality of Higher Education in China: How Likely Would Chinse Poor Students Get to Success? Higher Education Research \& Development, 37(5): 10151034 .

Luo, Z. - Qin, Z. (2012): SWOT Analysis of Functions of Chinese Universities. IERI Procedia, 2: 253-257.

Ma, W. (2007): The Flagship University and China's Economic Reform. In: Altbach, P. G. - Balán, J. (eds): World Class Worldwide: Transforming Research Universities in Asia and Latin America. Baltimore: The John Hopkins University Press, pp. 31-53.

Nofri, E. M. (2015): The University System in China. 9 July, 2015. http://www.albertoforchielli.com/theuniversity-system-in-china/. Retrieved at 15 April 2020.

People's Daily (2009): Editor Note. http://en.people.cn/203691/7822275.html. Retrieved at 15 April 2020.

QS World University Ranking. https://www.topuniversities.com/university-rankings, Retrieved at 4 April 2020.

Salmi, J. (2009): The Challenge of Establishing World Class Universities, Directions in Development. Human Development, No. 47610. Washington, DC: World Bank Publishing.

Sanger, J. - Baer, J. (2019): Fall 2019 International Student Enrolment Snapshot Survey. IIE Center for Academic Mobility Research and Impact, November, pp. 1-12.

Sharma, Y. (2020): China Shifts from Reliance on International Publications. University World News, https://www.universityworldnews.com/post.php?story $=20200225181649179$. Retrieved at 15 April 2020.

Shen, G. (2018): Building World-Class Universities in China: From the View of National Strategies. Global University Network for Innovation. http://www.guninetwork.org/articles/building-world-classuniversities-china-view-national-strategies. Retrieved at 15 April 2020.

Shi, L. - Liu, R. - Kang, Y. (2020): Does a Name Change Attract Better Students? Evidence from Chinese Universities. China Economic Review, 60(April): 1-13.

Taber, N. (2018): How Xi Jinping is Shaping China's Universities. The Diplomat, August 10, 2018. https:// thediplomat.com/2018/08/how-xi-jinping-is-shaping-chinas-universities/. Retrieved at 4 May 2020. 
Teichler, U. (2010): The Challenges of Almost Universal Higher Education. In: Organizing Committee of Sino-Finnish Higher Education Symposium (ed.): The Challenges and Experience in the Post-Massifcation Era. Beijing, pp. 10-19.

Textor, C. (2019): Number of Chinese Students in the U.S. 2008/09-2018/2019. https://www.statista.com/ statistics/372900/number-of-chinese-students-that-study-in-the-us/. Retrieved at 10 May 2020.

Times Higher Education World University Ranking. https://www.timeshighereducation.com/worlduniversity-rankings/2020/world-ranking\#!/page/0/length/25/sort_by/rank/sort_order/asc/cols/stats. Retrieved at 04 April 2020.

Wang, A. Z. (2018): Fewer Chinese to Stay Abroad after Graduation - Survey. https://www. universityworldnews.com/post.php?story $=20180531154955271$. Retrieved at 10 May 2020.

Web of Science. https://apps.webofknowledge.com/WOS_GeneralSearch_input.do?product=WOS\&search_ mode $=$ GeneralSearch $\&$ SID $=$ D2HEBXBCl5yuwP16FFc\&preferencesSaved $=$. Retrieved at 4 April 2020.

Xin, H. - Dennis, N. (2008): Gunning for the Ivy League. Science, 319(January): 148-151.

Yaisawarng, S. - Ng, Y. C. (2014): The Impact of Higher Education Reform on Research Performance of Chinese Universities. China Economic Review, 31(December): 94-105.

Yang, R. (2006): Toward Massification: Higher Education Development in the People's Republic of China since 1949. In: Smart, J. C. (ed.): Higher Education Handbook of Theory and Research. Vol. 20. Dordrecht: Springer Publisher, pp. 311-374. 


\section{APPENDIX 1 UNIVERSITY RANKINGS}

The best Chinese universities which were ranked by all three international rankings (THE, ARWU and QS) at least in one year between 2017 and 2019. The universities were ordered according to the ARWU 2019 ranking.

\begin{tabular}{|c|c|c|c|c|c|c|c|c|c|}
\hline \multirow{2}{*}{$\begin{array}{l}\text { The best } \\
\text { universities of } \\
\text { China } \\
\text { (Mainland) }\end{array}$} & \multicolumn{3}{|c|}{ Times } & \multicolumn{3}{|c|}{ ARWU } & \multicolumn{3}{|c|}{ QS } \\
\hline & 2017 & 2018 & 2019 & 2017 & 2018 & 2019 & 2017 & 2018 & 2019 \\
\hline $\begin{array}{l}\text { Tsinghua } \\
\text { University }\end{array}$ & - & 30 & 22 & 48 & 45 & 43 & 24 & 25 & 17 \\
\hline $\begin{array}{l}\text { Peking } \\
\text { University }\end{array}$ & 29 & 27 & 31 & 71 & 57 & 53 & 39 & 38 & 30 \\
\hline $\begin{array}{l}\text { Zhejiang } \\
\text { University }\end{array}$ & $201-250$ & 77 & 101 & $101-150$ & 67 & 70 & 110 & 87 & 68 \\
\hline $\begin{array}{l}\text { Shanghai Jiao } \\
\text { Tong } \\
\text { University }\end{array}$ & $201-250$ & 88 & 89 & $101-150$ & $101-150$ & 82 & 61 & 62 & 59 \\
\hline $\begin{array}{l}\text { Fudan } \\
\text { University }\end{array}$ & 155 & 116 & 104 & $101-150$ & $101-150$ & $101-150$ & 43 & 40 & 44 \\
\hline $\begin{array}{l}\text { Huazhong } \\
\text { University of } \\
\text { Science and } \\
\text { Technology }\end{array}$ & $401-500$ & $401-500$ & $351-400$ & $201-300$ & $151-200$ & $101-150$ & $441-450$ & $471-480$ & 415 \\
\hline $\begin{array}{l}\text { Sun Yat-sen } \\
\text { University }\end{array}$ & $401-500$ & $351-400$ & $301-350$ & $151-200$ & $101-150$ & $101-150$ & 297 & 319 & 295 \\
\hline $\begin{array}{l}\text { University of } \\
\text { Science and } \\
\text { Technology } \\
\text { of China }\end{array}$ & 153 & 132 & 93 & $101-150$ & $101-150$ & $101-150$ & 104 & 98 & 97 \\
\hline \multirow[t]{2}{*}{$\begin{array}{l}\text { Central South } \\
\text { University }\end{array}$} & $801+$ & $601-800$ & $601-800$ & $301-400$ & $201-300$ & $151-200$ & & $\begin{array}{c}801- \\
1,000\end{array}$ & $\begin{array}{l}801- \\
100\end{array}$ \\
\hline & $501-600$ & $501-600$ & $401-500$ & $151-200$ & $151-200$ & $151-200$ & 278 & 325 & 285 \\
\hline
\end{tabular}

(continued) 
Continued

\begin{tabular}{|c|c|c|c|c|c|c|c|c|c|}
\hline \multirow{2}{*}{$\begin{array}{l}\text { The best } \\
\text { universities of } \\
\text { China } \\
\text { (Mainland) }\end{array}$} & \multicolumn{3}{|c|}{ Times } & \multicolumn{3}{|c|}{ ARWU } & \multicolumn{3}{|c|}{ QS } \\
\hline & 2017 & 2018 & 2019 & 2017 & 2018 & 2019 & 2017 & 2018 & 2019 \\
\hline \multicolumn{10}{|l|}{$\begin{array}{l}\text { Harbin Institute } \\
\text { of } \\
\text { Technology }\end{array}$} \\
\hline $\begin{array}{l}\text { Nanjing } \\
\text { University }\end{array}$ & $601-800$ & 169 & 134 & 201-300 & $151-200$ & $151-200$ & 115 & 114 & 122 \\
\hline $\begin{array}{l}\text { University of } \\
\text { Electronic } \\
\text { Science and } \\
\text { Technology } \\
\text { of China }\end{array}$ & $801+$ & $\begin{array}{c}801- \\
1,000\end{array}$ & & $201-300$ & $201-300$ & $151-200$ & & & $\begin{array}{l}751- \\
800\end{array}$ \\
\hline $\begin{array}{l}\text { Sichuan } \\
\text { University }\end{array}$ & $601-800$ & $601-800$ & $601-800$ & $151-200$ & $151-200$ & $151-200$ & $551-600$ & & $\begin{array}{l}601- \\
650\end{array}$ \\
\hline $\begin{array}{l}\text { Southeast } \\
\text { University }\end{array}$ & $501-600$ & $501-600$ & $501-600$ & 201-300 & $201-300$ & $151-200$ & $501-550$ & $501-550$ & $\begin{array}{l}511- \\
520\end{array}$ \\
\hline $\begin{array}{l}\text { Wuhan } \\
\text { University }\end{array}$ & $401-500$ & $401-500$ & $301-350$ & 201-300 & 201-300 & $151-200$ & 275 & 282 & 257 \\
\hline $\begin{array}{l}\text { Beihang } \\
\text { University }\end{array}$ & & $601-800$ & $501-600$ & $301-400$ & 201-300 & $201-300$ & $431-440$ & $551-600$ & 491 \\
\hline $\begin{array}{l}\text { Beijing Normal } \\
\text { University }\end{array}$ & & & & $201-300$ & $201-300$ & $201-300$ & 257 & 256 & 292 \\
\hline $\begin{array}{l}\text { Dalian } \\
\text { University of } \\
\text { Technology }\end{array}$ & $601-800$ & $601-800$ & $601-800$ & $301-400$ & 201-300 & $201-300$ & $481-490$ & $551-600$ & $\begin{array}{l}571- \\
580\end{array}$ \\
\hline Jilin University & $601-800$ & & $\begin{array}{l}801- \\
1,001\end{array}$ & $301-400$ & $201-300$ & $201-300$ & $491-500$ & $491-500$ & 475 \\
\hline $\begin{array}{l}\text { Nankai } \\
\text { University }\end{array}$ & & & $351-400$ & $301-400$ & $301-400$ & $201-300$ & 315 & 344 & 338 \\
\hline $\begin{array}{l}\text { Shandong } \\
\text { University }\end{array}$ & & $501-600$ & $501-600$ & $301-400$ & $301-400$ & $201-300$ & $501-550$ & $551-600$ & $\begin{array}{l}541- \\
550\end{array}$ \\
\hline $\begin{array}{l}\text { South China } \\
\text { University of } \\
\text { Technology }\end{array}$ & $601-800$ & $501-600$ & $501-600$ & 201-300 & $201-300$ & $201-300$ & $551-600$ & $551-600$ & $\begin{array}{l}541- \\
550\end{array}$ \\
\hline
\end{tabular}

(continued) 


\section{Continued}

\begin{tabular}{|c|c|c|c|c|c|c|c|c|c|}
\hline \multirow{2}{*}{$\begin{array}{l}\text { The best } \\
\text { universities of } \\
\text { China } \\
\text { (Mainland) }\end{array}$} & \multicolumn{3}{|c|}{ Times } & \multicolumn{3}{|c|}{ ARWU } & \multicolumn{3}{|c|}{ QS } \\
\hline & 2017 & 2018 & 2019 & 2017 & 2018 & 2019 & 2017 & 2018 & 2019 \\
\hline $\begin{array}{l}\text { Tianjin } \\
\quad \text { University }\end{array}$ & $501-600$ & $501-600$ & $501-600$ & $301-400$ & 201-300 & $201-300$ & $481-490$ & $471-480$ & 443 \\
\hline $\begin{array}{l}\text { Tongji } \\
\text { University }\end{array}$ & $501-600$ & $401-500$ & $401-500$ & $301-400$ & $301-400$ & 201-300 & 315 & 316 & 291 \\
\hline $\begin{array}{l}\text { Beijing } \\
\text { Institute of } \\
\text { Technology }\end{array}$ & $601-800$ & $601-800$ & $601-800$ & & $401-500$ & $301-400$ & 389 & $451-460$ & 464 \\
\hline $\begin{array}{l}\text { China } \\
\text { Agricultural } \\
\text { University }\end{array}$ & $501-600$ & $601-800$ & $601-800$ & $401-500$ & $301-400$ & $301-400$ & & $701-750$ & $\begin{array}{l}651- \\
700\end{array}$ \\
\hline $\begin{array}{l}\text { Chongqing } \\
\text { University }\end{array}$ & $801+$ & $\begin{array}{r}801- \\
1,000\end{array}$ & $\begin{array}{r}801- \\
1,000\end{array}$ & & $401-500$ & $301-400$ & & $\begin{array}{r}801- \\
1,000\end{array}$ & $\begin{array}{l}801- \\
1,000\end{array}$ \\
\hline $\begin{array}{l}\text { East China } \\
\text { University of } \\
\text { Science and } \\
\text { Technology }\end{array}$ & $501-600$ & $601-800$ & $601-800$ & $301-400$ & $301-400$ & $301-400$ & $471-480$ & $551-600$ & $\begin{array}{l}531- \\
540\end{array}$ \\
\hline $\begin{array}{l}\text { Hunan } \\
\text { University }\end{array}$ & $601-800$ & $601-800$ & $501-600$ & $301-400$ & $301-400$ & $301-400$ & & $\begin{array}{c}701- \\
0.750\end{array}$ & $\begin{array}{l}701- \\
0.750\end{array}$ \\
\hline $\begin{array}{l}\text { Lanzhou } \\
\quad \text { University }\end{array}$ & & & $501-600$ & $301-400$ & $301-400$ & $301-400$ & $551-600$ & $601-650$ & $\begin{array}{l}601- \\
650\end{array}$ \\
\hline $\begin{array}{l}\text { Xiamen } \\
\text { University }\end{array}$ & $401-500$ & $401-500$ & $501-600$ & $301-400$ & $301-400$ & 201-300 & $451-460$ & $431-440$ & 476 \\
\hline
\end{tabular}

Note: The highlighted universities are the top 3 Chinese universities according to the THE, 2020 ranking. The ranking of these universities was analysed separately in Figure 1.

\section{APPENDIX 2}

\section{CORRELATIONS}




\begin{tabular}{|c|c|c|c|c|c|c|c|c|c|c|}
\hline & & Times2017 & Times2018 & Times2019 & ARWU2017 & ARWU2018 & ARWU2019 & QS2017 & QS2018 & QS2019 \\
\hline \multirow[t]{3}{*}{ Times 2017} & Pearson Correlation & 1 & $0.855^{* *}$ & $0.847^{* *}$ & $0.689^{* *}$ & $0.652^{* *}$ & $0.589^{* *}$ & $0.792^{* *}$ & $0.850^{* *}$ & $0.857^{* *}$ \\
\hline & Sig. (2-tailed) & & 0.000 & 0.000 & 0.000 & 0.000 & 0.001 & 0.000 & 0.000 & 0.000 \\
\hline & $\mathrm{N}$ & 28 & 27 & 27 & 26 & 28 & 28 & 21 & 24 & 26 \\
\hline \multirow[t]{3}{*}{ Times 2018} & Pearson Correlation & $0.855^{* *}$ & 1 & $0.952^{* *}$ & $0.709^{* *}$ & $0.742^{* *}$ & $0.735^{* *}$ & $0.862^{* *}$ & $0.911^{* *}$ & $0.902^{* *}$ \\
\hline & Sig. (2-tailed) & 0.000 & & 0.000 & 0.000 & 0.000 & 0.000 & 0.000 & 0.000 & 0.000 \\
\hline & $\mathrm{N}$ & 27 & 29 & 28 & 27 & 29 & 29 & 22 & 25 & 27 \\
\hline \multirow[t]{3}{*}{ Times 2019} & Pearson Correlation & $0.847^{* *}$ & $0.952^{* *}$ & 1 & $0.747^{* *}$ & $0.752^{* *}$ & $0.760^{* *}$ & $0.872^{* *}$ & $0.884^{* *}$ & $0.877^{* *}$ \\
\hline & Sig. (2-tailed) & 0.000 & 0.000 & & 0.000 & 0.000 & 0.000 & 0.000 & 0.000 & 0.000 \\
\hline & $\mathrm{N}$ & 27 & 28 & 31 & 29 & 31 & 31 & 25 & 28 & 29 \\
\hline \multirow[t]{3}{*}{ ARWU 2017} & Pearson Correlation & $0.689^{* *}$ & $0.709^{* *}$ & $0.747^{* *}$ & 1 & $0.867^{* *}$ & $0.839^{* *}$ & $0.721^{* *}$ & $0.805^{* *}$ & $0.681^{* *}$ \\
\hline & Sig. (2-tailed) & 0.000 & 0.000 & 0.000 & & 0.000 & 0.000 & 0.000 & 0.000 & 0.000 \\
\hline & $\mathrm{N}$ & 26 & 27 & 29 & 32 & 32 & 32 & 25 & 27 & 29 \\
\hline \multirow[t]{3}{*}{ ARWU 2018} & Pearson Correlation & $0.652^{* *}$ & $0.742^{* *}$ & $0.752^{* *}$ & $0.867^{* *}$ & 1 & $0.897^{* *}$ & $0.632^{* *}$ & $0.731^{* *}$ & $0.660^{* *}$ \\
\hline & Sig. (2-tailed) & 0.000 & 0.000 & 0.000 & 0.000 & & 0.000 & 0.001 & 0.000 & 0.000 \\
\hline & $\mathrm{N}$ & 28 & 29 & 31 & 32 & 34 & 34 & 26 & 29 & 31 \\
\hline \multirow[t]{3}{*}{ ARWU 2019} & Pearson Correlation & $0.589^{* *}$ & $0.735^{* *}$ & $0.760^{* *}$ & $0.839^{* *}$ & $0.897^{* *}$ & 1 & $0.683^{* *}$ & $0.739^{* *}$ & $0.634^{* *}$ \\
\hline & Sig. (2-tailed) & 0.001 & 0.000 & 0.000 & 0.000 & 0.000 & & 0.000 & 0.000 & 0.000 \\
\hline & $\mathrm{N}$ & 28 & 29 & 31 & 32 & 34 & 34 & 26 & 29 & 31 \\
\hline \multirow[t]{3}{*}{ QS 2017} & Pearson Correlation & $0.792^{* *}$ & $0.862^{* *}$ & $0.872^{* *}$ & $0.721^{* *}$ & $0.632^{* *}$ & $0.683^{* *}$ & 1 & $0.963^{* *}$ & $0.969^{* *}$ \\
\hline & Sig. (2-tailed) & 0.000 & 0.000 & 0.000 & 0.000 & 0.001 & 0.000 & & 0.000 & 0.000 \\
\hline & $\mathrm{N}$ & 21 & 22 & 25 & 25 & 26 & 26 & 26 & 25 & 26 \\
\hline
\end{tabular}




\begin{tabular}{|c|c|c|c|c|c|c|c|c|c|c|}
\hline & & Times2017 & Times2018 & Times2019 & ARWU2017 & ARWU2018 & ARWU2019 & QS2017 & QS2018 & QS2019 \\
\hline \multirow[t]{3}{*}{ QS 2018} & Pearson Correlation & $0.850^{* *}$ & $0.911^{* *}$ & $0.884^{* *}$ & $0.805^{* *}$ & $0.731^{* *}$ & $0.739^{* *}$ & $0.963^{* *}$ & 1 & $0.988^{* *}$ \\
\hline & Sig. (2-tailed) & 0.000 & 0.000 & 0.000 & 0.000 & 0.000 & 0.000 & 0.000 & & 0.000 \\
\hline & $\mathrm{N}$ & 24 & 25 & 28 & 27 & 29 & 29 & 25 & 29 & 29 \\
\hline \multirow[t]{3}{*}{ QS 2019} & Pearson Correlation & $0.857^{* *}$ & $0.902^{* *}$ & $0.877^{* *}$ & $0.681^{* *}$ & $0.660^{* *}$ & $0.634^{* *}$ & $0.969^{* *}$ & $0.988^{* *}$ & 1 \\
\hline & Sig. (2-tailed) & 0.000 & 0.000 & 0.000 & 0.000 & 0.000 & 0.000 & 0.000 & 0.000 & \\
\hline & $\mathrm{N}$ & 26 & 27 & 29 & 29 & 31 & 31 & 26 & 29 & 31 \\
\hline
\end{tabular}

Note: ${ }^{* *}$ Correlation is significant at the 0.01 level (2-tailed). 
APPENDIX 3

INTERNATIONAL OUTLOOK, INTERNATIONAL STUDENTS AND INTERNATIONAL FACULTY SCORES OF CHINESE UNIVERSITIES

\begin{tabular}{|c|c|c|c|c|c|}
\hline University & $\begin{array}{l}\text { International } \\
\text { students }\end{array}$ & $\begin{array}{l}\text { International } \\
\text { faculty }\end{array}$ & $\begin{array}{l}\text { QSOverall } \\
\text { ranking }\end{array}$ & $\begin{array}{l}\text { International } \\
\text { outlook }\end{array}$ & $\begin{array}{l}\text { THEOverall } \\
\text { ranking }\end{array}$ \\
\hline Tsinghua University & 30.1 & 68.0 & 16 & 47.4 & 23 \\
\hline Peking University & 36.9 & 70.7 & 22 & 59.6 & 24 \\
\hline Fudan University & 42.9 & 92.7 & 40 & 44.8 & 109 \\
\hline Zhejiang University & 62.9 & 95.4 & 54 & 61.8 & 107 \\
\hline $\begin{array}{l}\text { Shanghai Jiao Tong } \\
\text { University }\end{array}$ & 20.1 & 84.1 & 60 & 49.8 & 157 \\
\hline $\begin{array}{l}\text { University of Science and } \\
\text { Technology of China }\end{array}$ & 5.7 & 16.9 & 89 & 31.3 & 80 \\
\hline Nanjing University & 11.1 & 68.6 & 120 & 57.8 & 144 \\
\hline Wuhan University & 10.7 & 50.7 & 257 & 40.4 & $351-400$ \\
\hline Tongji University & 27.9 & 89.1 & 265 & 56.0 & $401-500$ \\
\hline Beijing Normal University & 30.4 & 23.6 & 277 & 42.9 & $301-350$ \\
\hline $\begin{array}{l}\text { Harbin Institute of } \\
\text { Technology }\end{array}$ & 10.0 & 10.8 & 277 & 36.7 & $401-500$ \\
\hline Sun Yat-sen University & 7.6 & 11.4 & 287 & 34.9 & $251-300$ \\
\hline Xi'an Jiatong University & 11.6 & 20.9 & 307 & 39.1 & $501-600$ \\
\hline Nankai University & 8.0 & 30.9 & 368 & 35.4 & $351-400$ \\
\hline $\begin{array}{l}\text { Huazhong University of } \\
\text { Science and Technology }\end{array}$ & 6.6 & 12.7 & 400 & 25.8 & $301-350$ \\
\hline
\end{tabular}

(continued) 


\section{Continued}

\begin{tabular}{|c|c|c|c|c|c|}
\hline University & $\begin{array}{l}\text { International } \\
\text { students }\end{array}$ & $\begin{array}{l}\text { International } \\
\text { faculty }\end{array}$ & $\begin{array}{l}\text { QSOverall } \\
\text { ranking }\end{array}$ & $\begin{array}{l}\text { International } \\
\text { outlook }\end{array}$ & $\begin{array}{c}\text { THEOverall } \\
\text { ranking }\end{array}$ \\
\hline Shanghai University & 5.2 & 46.3 & 412 & 31.0 & $801-1,000$ \\
\hline Tianjin University & 6.2 & 9.0 & 429 & 26.5 & $501-600$ \\
\hline $\begin{array}{l}\text { Beijing Insitute of } \\
\text { Technology }\end{array}$ & 8.1 & 5.0 & 436 & 24.3 & $601-800$ \\
\hline Xiamen University & 4.5 & 7.6 & 451 & 31.5 & $501-600$ \\
\hline $\begin{array}{l}\text { Beihang University (former } \\
\text { BUAA) }\end{array}$ & 6.2 & 10.1 & 462 & 28.7 & $501-600$ \\
\hline $\begin{array}{l}\text { University of Science and } \\
\text { Technology Beijing }\end{array}$ & 4.1 & 4.5 & 462 & 20.3 & $801-1,000$ \\
\hline Shandong University & 5.5 & 9.3 & 468 & 30.6 & $601-800$ \\
\hline $\begin{array}{l}\text { South China University of } \\
\text { Technology }\end{array}$ & 4.3 & 13.5 & 480 & 30.8 & $501-600$ \\
\hline Jilin University & 3.0 & 13.9 & 484 & 20.4 & $801-1,000$ \\
\hline $\begin{array}{l}\text { East China Normal } \\
\text { University }\end{array}$ & 28.7 & 60.6 & $531-540$ & 58.4 & $501-600$ \\
\hline
\end{tabular}

\section{APPENDIX 4}

\section{HUNGARIAN - CHINESE COMPARISON}

The International Outlook, International Faculty and International Student scores for the Hungarian top Universities were also analysed (Appendix Table 1). In the QS Ranking (2020) all top Hungarian HE institutions are positioned above 500 (501-510), while in the Times Higher Education Ranking (2020) the first Hungarian university is only ranked 401-500. Hungarian International Outlook scores are between 40 and 75 . The highest score belongs to Semmelweis University (75), while the lowest score was received by the Budapest University of Technology and Economics (34.7). The mean in this case is $51.64,{ }^{21}$ while the standard deviation is 12.29 .

\footnotetext{
${ }^{21}$ All higher education institutions which were present in both international university rankings (QS and THE) were taken in consideration as Hungarian universities. Our analysis was not restricted to only those institutions which received International Outlook, International Faculty and also International Student scores. This would have resulted in a very short list, especially taking into consideration that none of the Hungarian universities received International Faculty index scores.
} 
The International Outlook (THE 2020), International Faculty, International Students (QS, 2020) scores for the top Hungarian universities

\begin{tabular}{|l|c|c|c|}
\hline & $\begin{array}{c}\text { Times higher education ranking } \\
\mathbf{( 2 0 2 0 )}\end{array}$ & \multicolumn{2}{|c|}{ QS ranking (2020) } \\
\cline { 3 - 4 } & International outlook & $\begin{array}{c}\text { International } \\
\text { faculty }\end{array}$ & $\begin{array}{c}\text { International } \\
\text { students }\end{array}$ \\
\hline Semmelweis University & 75.00 & N.a. & N.a. \\
\hline Eötvös Loránd University & 52.60 & N.a. & 19.10 \\
\hline University of Debrecen & 55.70 & N.a. & 74.50 \\
\hline University of Pécs & 55.90 & N.a. & 64.70 \\
\hline University of Szeged & 54.40 & N.a. & 58.40 \\
\hline $\begin{array}{l}\text { Budapest University of Technology } \\
\text { and Economics }\end{array}$ & 34.70 & N.a. & 15.30 \\
\hline Coninus University of Budapest & 44.70 & N.a. & 37.50 \\
\hline Szent István University & 40.10 & N.a. & N.a. \\
\hline Mean & 51.64 & & 44.92 \\
\hline
\end{tabular}

Source: THE and QS database, own compilation and calculation.

The International Student scores are between 15.30 and 74.50. The mean value is 44.92 , while the standard deviation is 24.69. The highest score belongs to the University of Debrecen, while the Budapest University of Technology and Economics, here too, received the lowest score among Hungarian competitors.

The overall ranking positions of the HE institutions of China are much higher than for the universities of Hungary (see e.g. the ranking of the 'best' Chinese vs. the 'best' Hungarian university in the THE ranking: 23 compared to 401-500). Comparing the International Outlook and International Student rankings, the picture somewhat changes. The mean values for both the International Outlook and International Student indices are higher for the Hungarian universities. ${ }^{22}$ Although the highest International Outlook score belonged to Zhejiang University in this two-country-comparison, the highest International Student score was for the University of Debrecen, Hungary. The mean values are higher and the standard

${ }^{22}$ Our results should be interpreted with caution, as the number of universities analysed for the two countries are very different. 
deviations are lower for the Hungarian universities. It is true for both countries however, that higher ranked universities do not necessarily have higher International Outlook and International Student scores.

Open Access. This is an open-access article distributed under the terms of the Creative Commons Attribution 4.0 International License (https://creativecommons.org/licenses/by/4.0), which permits unrestricted use, distribution, and reproduction in any medium, provided the original author and source are credited, a link to the CC License is provided, and changes - if any - are indicated. (SID_1) 